\title{
Colobomatous microphthalmia
}

INSERM

\section{Source}

INSERM. (1999). Orphanet: an online rare disease and orphan drug data base.

Colobomatous microphthalmia. ORPHA:98938

Colobomatous microphthalmia is a developmental disorder of the eye characterized by unilateral or bilateral microphthalmia associated with ocular coloboma. 